\title{
NILAI-NILAI KARAKTER PADA TEKNIK PATRI TAPAL KUDA LAMPU ANDONG DI KOTAGEDE YOGYAKARTA
}

\author{
Nurjayanto Prasetyo dan Marzuki \\ Universitas Negeri Yogyakarta \\ Email: nurjayantoprasetyo@gmail.com
}

\begin{abstract}
Abstrak: Penelitian ini bertujuan untuk mengetahui nilai-nilai karakter yang terkandung dalam teknik pematrian lampu andong Kotagede menggunakan alat tapal kuda. Jenis penelitian ini merupakan penelitian kualitatif dengan metode etnografi yang diuraikan dengan cara deskriptif menggunakan multimetode yang terfokus, melibatkan interpretasi, pendekatan alamiah pada materi subjek. Subjek penelitian yaitu budayawan dan pengrajin di Kotagede. Penelitian ini dilakukan di Dusun Mutihan Kotagede Yogyakarta. Peneliti mengunakan teknik pengumpulan data observasi partisipan, wawancara terstruktur, studi pustaka, dokumentasi, dan eksperimen. Pemeriksaan keabsahan data melalui kredibilitas, transferabilitas, dependabilitas, konsfirmabilitas, dan triangulasi. Analisis data menggunakan teknik analisis interaktif dengan tahap-tahap reduksi data, penyajian data, dan verifikasi data/penarikan simpulan. Hasil penelitian menunjukan bahwa teknik patri tapal kuda yang ampuh dan multiguna pada teknik mematri kriya logam juga memiliki nilai-nilai falsafah Jawa yang sudah tercermin dalam nilai-nilai karakter yang terdiri dari: urip iku urup (peduli sosial), alon-alon waton kelakon (tanggung jawab), nrimo ing pandum (jujur), aja adigang adigung adiguno (toleransi), dan memayu hayuning bawana ambrasta dur hangkara (religius).
\end{abstract}

Kata Kunci: nilai karakter, teknik patri, tapal kuda, lampu andong

\section{CHARACTER VALUES IN THE LIGHTING DESOLDERING TECHNIQUE ANDONG KOTAGEDE YOGYAKARTA USING HORSE SHOES TOOLS}

\begin{abstract}
This study aims to know the character education values contained in the lighting desoldering technique andong Kotagede using horse shoes tools. This research is a qualitative research with ethnographic methods described in a descriptive way using multi-focused methods, involving interpretations, natural approaches to subject matter. This research was conducted in Mutihan Kotagede Hamlet, Yogyakarta. Data collection used techniques of participant observation, structured interviews, literature studies, documentation and experiments. With the validity of the data through credibility, transferability, dependability, consistency and triangulation. Data analysis used interactive analysis techniques with stage data reduction, data presentation, and data verification/conclusion drawing. The result of this study is educational values of Javanese philosophical characters found in desoldering with horse shoes stained bolts on andong lights, namely urip iku urup (social care), alon-alon waton kelakon (responsibility), nrimo ing pandum (honest), aja adigang adigung adiguna (tolerance), memayu hayuning bawana ambrasta dur hungkara (religious).
\end{abstract}

Keywords: characters, desoldering technique, horse shoes, andong lights

\section{PENDAHULUAN}

Dewantara (1997:25) mendefinisikan nilai karakter sama dengan budi pekerti. Budi pekerti adalah bulatnya jiwa yang ada pada diri manusia. Jiwa berhubungan dengan roh atau batin yang tidak bisa dilihat namun bisa dirasakan. Budi pekerti atau karakter merupakan bersatunya pikiran, perasaan, dan kehendak, kemudian menim- bulkan tenaga yang bisa dilihat dan dirasakan. Seseorang dapat dikatakan memiliki budi pekerti atau karakter, apabila dalam perilakunya akan menanamkan nilai-nilai kebaikan seperti: taat dan menjauhi larangan Tuhan Yang Maha Esa, tolong-menolong, gotong-royong, dan sebagainya. Apabilaseseorang sudah memiliki karakter atau 
budi pekerti, maka kehadirannya dapat menjadi ciri khas yang berbeda dengan yang lain. Oleh sebab itu, setiap orang dapat dikenal berdasarkan watak atau karakternya.

Manusia yang memiliki karakter akan sesuai dengan fungsi dan tujuan Undang Undang Nomor 20 Tahun 2003 tentang Sistem Pendidikan Nasional. Dalam undangundang ini dijelaskan bahwa pendidikan nasional memiliki fungsi mengembangkan kemampuan dan membentuk watak serta peradaban bangsa yang bermartabat dalam rangka mencerdaskan kehidupan bangsa. Selain itu, pendidikan nasional juga bertujuan untuk mengembangkan potensi peserta didik supaya menjadi manusia yang beriman dan bertakwa kepada Tuhan Yang Maha Esa, berakhlak mulia, sehat, berilmu, cakap, kreatif, mandiri, dan menjadi warga negara yang demokratis serta bertanggung jawab.

Banyak cara yang dapat dilakukan untuk membentuk watak atau karakter, salah satunya dengan melestarikan dan menggali kandungan nilai karakter yang terdapat di dalam budaya, adat istiadat, kesenian, dan kerajinan yang selama ini masih dilestarikan di masyarakat. Salah satu hasil kerajinan yang dalam proses pembuatannya mengandung nilai-nilai karakter adalah teknik patri pada kerajinan logam di Kotagede Yogyakarta. Proses pengerjaannya masih menggunakan teknik patri tradisional, proses ini terdapat banyak falsafah Jawa yang identik dengan nilai-nilai karakter yang mampu membentuk watak manusia yang baik. Nilai-nilai karakter dalam falsafah Jawa ada bukan untuk membatasi gerak-gerak sifat manusia dalam berinteraksi, melainkan untuk menuntun sifat manusia menjadi lebih baik.

Seperti yang ada pada proses pembuatan lampu andong menggunakan alat dari tapal kuda atau yang disebut dengan patri tapal kuda. Teknik patri adalah menyambungkan bagian-bagian logam dengan menambahkan cairan logam yang suhu cairnya lebih rendah daripada logam yang dikerjakan (Sunaryo, 2000:25). Hal tersebut dapat dikerjakan sempurna apabila waktu melekatkan bagian-bagian logam tersebut dalam keadaan bersih, dan suhunya paling rendah sama dengan suhu logam penambah yang disebut logam patri.

Teknik patri tapal kuda adalah menyambungkan bagian-bagian logam menggunakan baut pematri atau alat pematri menggunakan alat yang terbuat dari tapal kuda. Teknik patri menggunakan alat yang terbuat dari tapal kuda mempunyai berbagai keunggulan yang dapat digunakan dalam penyambungan logam, yaitu dapat menyambungkan jenis logam yang berbeda. Selain mempunyai keunggulan yang bagus untuk dijadikan alat mematri, tapal kuda mempunyai historis maupun makna nilai karakter yang sangat dalam dalam kehidupan sehari-hari yang dapat diterapkan oleh pelaku pembuat kerajinan maupun oarng lain.

Patri tapal kuda sampai saat ini masih digunakan di wilayah Kotagede yang notabene sebagai sentra kerajinan logam di Daerah Istimewa Yogyakarta. Meskipun banyak teknik patri yang lebih modern seperti teknik patri menggunakan alat gembosan, soldier listrik dan gas asitilin, teknik ini tetap dilestarikan karena mempunyai keunggulan dan sejarah bagi lingkungan sekitar Kerajaan Mataram Islam Kotagede. Sehingga patri tapal kuda atau sepatu kuda sampai saat ini tetap dipertahankan dan dilestarikan oleh para pengrajin logam.

Tapal kuda mempunyai keunikan dan keunggulan dalam teknik pematrian, alat ini mempunyai sifat multiguna dalam mematri kerajinan yang berbahan logam. 
Di antara gunanya yakni sebagai alat mematri yang pertama adalah barang perkakas rumah tangga yang meliputi ceret dan wajan, yang kedua sebagai alat mematri wuwungan rumah joglo dan limasan, dan yang ketiga dapat digunakan untuk membuat dan menambal talang rumah joglo hingga limasan. Dalam pembuatan kriya logam bahan-bahan seperti perak, emas, kuningan, dan tembaga mempunyai karakter bahan yang berbeda tidak bisa disatukan dengan alat-alat modern seperti yang sudah disebutkan, tetapi sebaliknya dengan tapal kuda hal tersebut dapat disatukan.

Kenyataan seperti itu dipertegas oleh Bambang Winardi (67 tahun, perajin logam maupun budayawan Kotagede (wawancara pada tanggal 20 Agustus 2018) bahwa patri tapal kuda diartikan sebagai sebuah kepribadian masyarakat Kotagede yang kreatif dalam mengambil keputusan. Masyarakat kotagede harus tetap menjaga kepribadian dan menjalankan unsur lain di dalam falsafah Jawa dengan baik. Unsur-unsur di dalam falsafah Jawa adalah urip $i k u$ urup yang berarti sikap peduli sosial, alonalon waton kelakon yang bermaknakan rasa tanggung jawab, aja adigang adigung adiguno yang berarti toleransi dan disiplin, nrimo ning pandum mengajarkan kejujuran, serta memayu hayuning bawana ambrasta dur hangkara yang merupakan wujud bersyukur atas karunia Tuhann yang merupakan falsafah dari karakter religius.

Pendapat di atas menunjukkan patri tapal kuda bukan hanya sekedar alat namun juga proses penghayatan terhadap nilai-nilai falsafah Jawa yang menjadi kepribadian masyarakat Kotagede. Alat patri tapal kuda merupakan wujud menjaga dan melestarikan nilai-nilai kearifan lokal yang masih bertahan hingga saat ini. Nilai falsafah Jawa pada patri tapal kuda sangat perlu dilestarikan dan dipertahankan supa- ya generasi muda ke depan menyadari local genius patri tapal kuda Kotagede mempunyai nilai adiluhung dalam membangun karakter bangsa. Keunikan inilah yang menjadi dasar peneliti ingin mengungkap nilainilai karakter falsafah Jawa yang terkandung dalamproses teknik patri tapal kuda.

Uraian mengenai kandungan nilainilai karakter di dalam falsafah Jawa, terutama nilai karakter yang tersirat di dalam proses teknik patri tapal kuda sejalan dengan upaya Pemerintah dalam membangun karakter bangsa. Sutrina Wibawa (2014) menegaskan bahwa filosofi Jawa ternyata sejalan dengan esensi nilai-nilai pembentuk karakter dalam sistem pendidikan yang dirumuskan pemerintah. Ajaran-ajaran tersebut mengajarkan bagaimana seharusnya karakter manusia yang baik dan benar. Nilai nilai tersebut terdiri dari nilai religius dan ketaatan beribadah, kejujuran, toleransi, kedisiplinan, kerja keras, kemandirian, demokratis, bersahabat/komunikatif, cinta damai, peduli lingkungan, peduli sosial, keikhlasan, keadilan dan tanggung jawab. Dari kecocokan-kecocokan antara filsafat Jawa dan rumusan karakter manusia Indonesia yang diinginkan melalui pendidikan, jelaslah bahwa filsafat Jawa merupakan sumber pendidikan karakter.

Keluhuran nilai nilai karakter dalam falsafah hidup Jawa disadari atau tidak sebenarnya adalah telah menjadi sumber pendidikan karakter di Indonesia sejak dahulu kala karena pendidikan karakter merupakan istilah lain dari pendidikan budi pekerti yang digagas oleh Ki Hadjar Dewantara (Widodo, dkk, 2017: 174). Adapun rumusan oleh Pusat Kurikulum Balitbang Kemendiknas tentang nilai-nilai karakter bangsa yang harus dikembangan yang terdiri dari: (1) religius; (2) jujur; (3) toleransi; (4) disiplin; (5) kerja keras; (6) kreatif; (7) mandiri; (8) demokratis; (9) rasa ingin tahu; 
(10) semangat kebangsaan; (11) cinta tanah air; (12) menghargai prestasi; (13) bersahabat/ komunikatif; (14) cinta damai; (15) gemar membaca; (16) peduli lingkungan; (17) peduli sosial; dan (18) tanggung jawab (Kemendiknas, 2010:9-10). Dengan demikian, penelitian ini bertujuan untuk mengungkap nilai-nilai karakter dalam falsafah Jawa yang terkandung dalam proses pembuatan kerajinan logam mengunakan teknik patri tapal kuda.

\section{METODE}

Jenis penelitian yang digunakan yaitu penelitian kualitatif dengan jenis etnografi yang diuraikan dengan cara deskriptif menggunakan multimetode yang fokus, melibatkan interpretasi, dan pendekatan alamiah pada materi subjek. Adapun penentuan subjek penelitian dilakukan dengan cara purposive yang disesuaikan dengan tujuan penelitian (Sugiyono, 2013:301). Cara ini dengan menentukan orang yang dianggap paling tahu tentang informasi yang dibutuhkan dalam penelitian, sehingga akan memudahkan peneliti dalam mengungkap tujuan penelitian. Adapun subjek yang dipilih adalah budayawan masyarakat Kotagede, pengrajin lampu andong kereta kencana, dan pengguna lampu andong kereta kencana di Kotagede.

Penelitian inidilakukan di Dusun Mutihan Kotagede, Yogyakarta. Adapun pelaksanaan penelitian mulai dari Bulan September 2017 sampai dengan Bulan Januari 2019. Dalam pengumpulan data peneliti menggunakan teknik observasi partisipan, wawancara terstruktur, studi pustaka, dokumentasi, dan eksperimen. Pemeriksaan keabsahan data melalui kredibilitas, transferabilitas, dependabilitas, konsfirmabilitas serta triangulasi. Analisis data dalam penelitian ini menggunakan teknik interaktif model Miles and Huberman (1994) dengan tahap-tahap reduksi data, penyajian data serta verifikasi data atau penarikan kesimpulan.

\section{HASIL DAN PEMBAHASAN}

Teknik patri tapal kuda pada lampu andong ketera kencana merupakan teknik parti tradisional. Teknik ini masih dipertahankan oleh sebagian pengrajin di Kotagede, meskipun teknik patri yang lebih modern lebih mudah digunakan. Menurut Bambang Winardi selaku Tokoh Pengiat Warisan Budaya Kotagede (wawancara tanggal 30 September 2017) alasan digunakan dan masih dilestarikan teknik patri ini karena kandungan nilai-nilai karakter dalamfalsafah Jawa dalam setiap proses pembuatannya.

Adapun nilai-nilai karakter yang terkandung pada proses teknik patri tapal kuda lampu andong diuraikan ke dalam langkah-langkah pembuatan tapal kuda sebagai berikut ini.

\section{Ngondel dan Mengungsil}

Ngondel merupakan proses pembentukan plat-plat logam menggunakan palu bermata setengah bola, sedangkan mengungsil adalah memipihkan dan melebarkan plat-plat logam menggunakan palu pengungsil. Plat-plat logam inilah yang nantinya disatukan dan disusun secara berurutan. Dibutuhkan kesabaran dan ketelitian dikarenakan dalam membentuk, merangkai diurutkan satu persatu dari bagian atas ke bawah supaya mendapat kontruksi yang benar. Kontruksi ini memiliki makna tersendiri bagi para pengrajin. Pembuatan lampu andong menggunakan baut patri tapal kuda diperhatikan pada setiap langkahnya dari pemilihan baut patri, pemotongan plat, dan pembentukan plat logam dengan cara ngondel dan mengungsil. 
Pada saat melakukan proses ini, peneliti melihat proses dan ikut terlibat secara langsung. Sukirman memaparkan (wawancara pada tanggal 19 September 2017) kandungan nilai karakter dalam proses ini dengan pernyataannya sebagai berikut.

Lampu andong kereto kencono katah sek saget di sinauni, amergo kereto kencono iku okeh pangilonne pangguripan soko ngondel karo ngungsil lungguhan ne, awak e, lan mondholanne. Sek lungguhan ne kui sokone urip, awak e okeh wujud e urip seko kotak, bunder, segitiga lan sak liyane, mondholane iku sek ngawe urip. Makane kui ojo sok ngendelke bondho, jabatan ngo nyilikke wong cilek amergo ora ono sek iso ngalahke sek ngawe urip.

Pernyataan tersebut memiliki arti bahwa proses pembuatan lampu andong kereta kencana banyak yang dapat dipelajari karena banyak pencerminan kehidupan dari cara mengondel dan mengungsil dudukannya, badannya, dan atapnya. Dudukannya itu ibarat pondasi kehidupan, setiap orang harus memiliki pondasi moral untuk dijadikan pedoman nilai dalam pergaulan. Selanjutnya rangkaian badannya merupakan bentuk-bentuk dari kehidupan yang berbentuk segi empat, bulat, dan segi tiga. Seperti kehidupan manusia, banyak komponen yang harus dimiliki manusia untuk menjalani hidup. Sedangkan atap lampu andong merupakan cerminan kepercayaan dan pelindung yang diberikan Tuhan Yang Maha Kuasa. Maka dari itu, hidup jangan memamerkan harta kekayaan dan jabatan, karena hal itu tidak akan bisa mengalahkan Kuasa dari Tuhan Yang Maha Esa.

Wakhid (wawancara pada tanggal 10 November 2017) menjelaskan bahwa struktur kehidupan itu harus melalui proses berjenjang, seperti susunan lampu andong yang memiliki dasar, badan, hingga atap. Hal yang patut diingat dari proses itu adalah tetap rendah hati meskipun sudah ber- ada di puncak kejayaan. Wakhid menyampaikan bahwa sudah selayaknya jadi wong Jawa kudu nduwe watak andhap asor lan lembah manah, mestine menungso ki ojo dumeh. Maksud dari falsafah ini adalah manusia seharusnya rendah hati dan ramah kepada siapa saja, jangan mentang-mentang memiliki kekuasaan atau jabatan bertindah sombong dan merugikan orang lain.

Proses ngondel dan mengungsil merupakan cerminan dari falsafah Jawa yaitu aja adigang, adigung, adiguna (kekayaan, kekuatan, dan kekuasaan). Makna yang terkandung dalam falsafah ini sebagaimana dijelaskan oleh Hariwijaya (2006:45) yakni manusia dapat dikatakan memiliki kekuatan apabila memiliki kekayaan yang berlimpah, kekuatan yang besar, dan dudukan kekuasaan tinggi. Sudah seharusnya orang yang memiliki kekuatan berkewajiban melindungi orang yang lebih lemah dan membutuhkan pertolongan orang lain, bukan sebaliknya. Dengan demikian orang yang menyombongkan kepemilikan harta benda, kekuatan fisik, dan jabatan kekuasaan tidak akan menjadikan manusia bahagia, sebaliknya sikap orang yang ambeg adil paramarta akan membuat orang memiliki sifat simpati dan empati terhadap keberadaan sesama manusia.

Ungkapan adigang, adigung, adiguna merupakan falsafah Jawa yang arif. Falsafah ini menjadi nasihat yang pas untuk manusia yang sedang memiliki kekuatan, kedudukan, dan kekuasaan. Orang seperti itu diharapkan mampu memegang kendali atas dirinya, sehingga tidak terjerumus pada perilaku angkuh dan sombong. Orang bijak harus semakin menyadari bahwa semakin tinggi kedudukannya akan semakin tampak kekurangan pada dirinya (Jatirahayu, 2013:267). Hal ini karena pada proses pembuatan lampu andong atau kereta kencana mempunyai struktur kontruksi de- 
ngan penjelasan bagian bawah berupa fondasi, bagian tengah berupa bentuk kehidupan yang terwujud dalam berbagai macam bentuk, dan paling atas merupakan perwujudan kepercayaan kepada Tuhan Yang Maha Esa. Falsafah Jawa aja adigang, adigung, adiguno memiliki persamaan makna dengan nilai-nilai karakter yang sudah dicanangkan oleh Pemerintah RI, yakni karakter religius dengan memiliki kepercayaan bahwa kehidupan merupakan pemberian Tuhan (Winarsih, Utomo, \& Ahmad, 2017). Selain itu, falsafah ini memiliki kandungan nilai karakter toleransi yakni dengan tidak memamerkan harta, jabatan, kekuasaan, dan rendah hati. Selain itu terdapat karakter peduli sosial dengan memiliki rasa empati dan simpati yang diwujudkan dengan cara memberikan pertolongan kepada sesama manusia.

\section{Ngharang Baut Patri Tapel Jaran}

Proses ngharang baut patri tapel jaran merupakan proses memanaskan baut patri tapal kuda ke dalam tungku bara api yang tebuat dari arang kayu, proses ini dilakukan sebelum melakukan pematrian platplat logam. Alasan menggunakan bara api arang karena mempunyai membuat karakteryang berbeda dari bara api lainya yang dihasilkan dari gas maupun minyak. Arang kayu mempunyai karakter api yang baik dengan menghasilkan panas yang khas, panas ini mampu bertahan lama pada baut patri tapal kuda. Proses memanaskan baut patri ini menurut penjelasan Sukirman (wawancara tanggal 17 September 2017) bahwa urip iku koyo geni areng iki sek iso ngewenehi manfaat kagem sek mbutuhne. Merganipun urip iku mboten saget dewe, kabeh niku mesti mbutuhke marang liyan. Paparan tersebut memiliki arti bahwa hidup itu seperti bara api arang yang mampu memberikan manfaat pada orang lain. Seperti halnya hidup yang tidak dapat dilakukan dengan sendirian, sehingga membutuhkan bantuan dari orang lain.

Penggunaan bara api dari arang kayu sebagai pemanas baut patri tapal kuda merupakan langkah-langkah penjabaran dari makna falsafah Jawa urip iku urup. Hariwijaya (2006:86) menegaskan bahwa manusia hidup harusnya mampu memberi manfaat bagi orang lain di sekitar. Semakin besar manfaat yang dapat diberikan tentu akan semakin lebih baik. Kandunagn nilai karakter dalam falsafah urip iku urup sejalan dengan pedoman nilai-nilai karakter yang ditetapkan Pemerintah, yakni karakter peduli sosial (Masrukhan, 2016). Karakter ini mengisyaratkan adanya hubungan timbal balik yang menguntungkan antara sesama manusia. Selain itu, karakter peduli lingkungan juga termuat dalam proses ini, karena arang berasal dari kayu, kayu berasal dari pohon. Dengan demikian, manusia harus menjaga ekosistem lingkungan hidup dengan menanam pohon supaya mampu menghasilkan arang yang dibutuhkan bara apinya.

Wakhdid menegaskan pernyataan sebelumnya tentang falsafah urip iku urup dengan istilah lainnya, yakni migunani tumraping liyan. Ibarat bara api yang menyala mesti digunakan untuk kebaikan, bukan untuk menciptakan 'hawa panas' dalam kehidupan. Api itu dibutuhkan untuk hal kebaikan, bukan untuk menyulut api kemarahan (wawancara pada tanggal 3 Maret 2018). Dari pernyataan ini dapat dipahami bahwa bara api arang yang terbuat dari kayu tersebut dalam pembuatan lampu andong atau kereta kencana akan menghasilkan panas yang dibutuhkan. Bara api ini akan bermanfaat apabila digunakan secara tepat dan cermat, maka di zaman yang sekarang ini masyarakat sudah sangat tidak memahami makna api yang selalu di- 
anggap sesuai simbol kehancuran. Arangpun sekarang tidak dihargai dan langka dikarenakan hutan-hutan semua dibabat habis demi kepentingan yang lain, arang sudah banyak tergusur oleh bahan bakar yang praktis seperti minyak, gas, dan listrik.

\section{Ngores Rejoso}

Pada pembuatan lampu andong kereta kencana terdapat teknik yang pokok karena bertujuan untuk menyatukan bagian plat logam antara satu dengan yang lainnya. Ngores rejoso merupakan proses mengoreskan baut patri tapal kuda yang sudah panas pada rejoso dan gondorukem. Langkah langkahnya dimulai dari memanaskan tapal kuda, oleskan air keras, dan taburkan gondorukem pada permukaan plat logam. Selanjutnya goreskan patri dengan cara ditarik mundur perlahan, supaya hasil pematrian tersebut merata dan menutup bagian plat yang disatukan.

Selaku pengrajin lampu andong, Sukirman (wawancara pada tanggal 19 September 2017) menjelaskan proses ini dengan Bahasa Jawa bahwa "Nek matri nganggo tapel jaran iku kudu alon-alon ora iso kesusu, nek kesusu rejoso mboten bakal nutup sek arep dipatri. Menopo kudu alon-alon supoyo kasile iku apik, alon-alon nek matri nganggo tapel jaran iku yo mboten mesti keri". Paparan tersebut memiliki arti bahwa proses mematri menggunakan tapal kuda itu harus dengan cara pelan-pelan tidak dapat tergesa-gesa, apabila tergesa-gesa maka patri tidak akan menutup bagian yang akan disatukan. Proses itu harus dilakukan secara perlahan supaya hasil pematrianya bagus dan sempurna. Dari paparan tersebut peneliti mendapatkan nilai karakter Jawa dalam proses ngores rejoso yakni alon-alon waton kelakon.
Hariwijaya (2006:13) menyatakan bahwa falsafah alon-alon waton kelakon dalam pekerjaan memiliki dua tujuan sekaligus dalam satu proses. Tujuan tersebut yaitu tercapai tujuan yang diingingkan dan keselamatan diri dalam bekerja. Prinsip melakukan pekerjaan menurut falsafah ini tepat cara bekerja dan tepat waktu. Tepat cara bekerja artinya bersunguh-sunguh dan tidak sembarangan, sedangkan tepat waktu artinya tidak terburu-buru dan tidak terlambat. Jika dihadapkan pada keadaan genting sekalipun dan harus segera menentukan pilihan, maka orang jawa akan memilih melakukan dengan perlahan yang penting hasil sempurna. Filosofi ini menuntun orang untuk bekerja dengan keselamatan.

Menurut Hernanda Rizky (2018: 329) kandungan makna alon-alon waton klakon sangatlah dalam, yakni mengisyaratkan tentang kehati-hatian, waspada, cekatan, keuletan, dan keselamatan bekerja. Jadi, dalam melakukan apa pun harus didasari dengan kehati-hatian, dan tidak tergesagesa supaya selamat. Artinya, dalam menghadapi permasalahan supaya dapat berpikir dengan kepala dingin, tetap tenang, tidak terburu-buru, dan tidak panik supaya dapat mencari jalan keluar dengan baik dan tepat.

Dalam bekerja, orang-orang Jawa itu terlihat lebih santai dan tidak ngoyo. Hal itu dikarenakan mereka memiliki prinsip alonalon waton kelakon. Artinya, meskipun perlahan-lahan dalam melakukan sesuatu yang penting dapat terselesaikan. Menjalani hidup harus dengan kesederhanaan, karena sejatinya inti dari kebahagiaan hidup terletak pada menikmati proses hidup yang sedang dilakukan. Kekayaan yang diangan-angankan tidak selalu menjamin kebahagiaan, sehingga bekerja tidak perlu tergesa dan berambisi berlebihan. Hal ini mengisyaratkan untuk fokus pada apa 
yang sudah dimiliki seperti keluarga, kerabat tanpa memusingkan sesuatu yang belum dimiliki (Kurnia, 2017). Orang Jawa dalam menlakukan pekerjan selalu punya prinsip alon-alon waton klakon, artinya tak bertindak gegabah yang penting terlaksana dan menyenangkan (Suwardi, 2018:172).

Dengan mengikuti tahapan seperti itulah akan didapat hasil pematrian yang halus dan rapi dan dapat menutup sambungan. Makna dari cara menggoreskan baut pematri alon-alon waton kelakon yang mempunyai penjelasan filosofi masyarakat Jawa sebagai langkah-langkah dalam bekerja yang cermat, tepat, dan tepat. Kandungan nilai karakter ini apabila dikaitkan dengan nilai-nilai karakter yang ditetapkan Pemerintah masuk ke dalam karakter tanggung jawab.

\section{Nyetel Jeronan}

Seletah susunan badan lampu andong dan mondholan sudah selesai dipatri, langkah selanjutnya adalah nyetel jeronan. Langkah ini dengan cara memasang lampu yang disebut sentir yang terdiri dari bagian atas untuk sumbu api dan bagian bawah untuk tempat minyak. Pada proses ini diperlukan ketelitian untuk nyetel sentir tersebut dikarenakan sentir tersebut mempunyai bidang yang kecil.

Sukirman (wawancara tanggal 19 September 2017) menjelaskan tips melakukan proses ini sebagai berikut ini.

Nek kabeh dilakoni kanthi legowo karo seneng, gaweane arep angel e koyo opo mesti gampang dilakoni. Waton legowo karo seneng matri ngango tapel jaran ne mesti iso wong matri nganggo tapel jaran kui ngajarke urip seng legowo, nrimo ing pandum. Sik durung apik yo dibaleni dibenake. Kabeh gawean nek dilakoni kanthi seneng lan ikhlas ora bakal ciloko.

Paparan tersebut berarti proses pembuatan yang dilakukan harus dengan hati yang ikhlas dan senang, sehingga pekerjaan sesulit apa pun akan mudah dilakukan. Pekerjaan harus diterima apa adanya dan dengan senang hati. Begitu juga apabila hasil nyetel belum sempurna dapat diperbaiki dengan mengulangi sampai benar-benar pas. Ikhlas dan senang pada proses mematri dengan tapal kuda mengajarkan hidup untuk menerima apa pun pekerjaan yang sedang dilakukan dengan senang hati.

Hariwijaya (2006:85) menjelaskan makna falsafah Jawa nrimo ing pandum sebagai sikap yang menunjukkan kejujuran, keiklasan hati, ringan dalam bekerja dan ketidakinginan yang berlebihan di luar nalar kehidupan. Pengerjaan lampu andong atau kereta kencana yang rumit dan tradisional tersebut juga mengajarkan nilai karakter untuk nrimo ing pandum. Dalam falsafah Jawa, kata tersebut mengandung arti orang harus menerima hasil dengan iklhas dari usaha yang sudah dikerjakan. Apabila belum sempurna maka dapat diperbaiki.

Proses ini sekaligus menunjukan karakter para pengrajin lampu andong kereta kencana. Sifat tersebut terbukti dengan tetap menerima keadaanya sebagai pengrajin logam yang bernilai ekonomis sekaligus pelestari budaya. Selain itu, pengrajin tetap konsisten mengunakan teknik patri ini meskipun banyak teknik patri yang modern. Hal yang ditekankan oleh para pengrajin adalah proses yang teliti penuh pemaknaan nilai filosofinya, terlebih lagi hasilnya akan digunakan pada kereta andong yang merupakan simbol karya budaya masyarakat Kotagede.

Seperti yang disampaikan Wakhid (wawancara tanggal 3 Maret 2018) bahwa proses nyetel jeroan ibarat membentuk diri manusia untuk menjadi manusia yang paripurna. Kebiasaan dan watak yang belum sesuai dapat disetting sedemikian rupa supaya menjadi manusia yang memiliki ke- 
pribadian yang baik dan mantap. Lampu andong kereta kencana sampai sekarang masih memepertahankan dalam penggunaan alat dan bahan-bahan yang tradisional semata-mata bukan karena ketertinggalan zaman, tetapi dengan tahapan seperti itulah karya menjadi mempunyai kuwalitas nilai falsafah Jawa dalam proses pembuatannya.

Nilai karakter pada falsafah nrimo ing pandum ini sama seperti deskripsi nilai karakter jujur. Aktualisasinya dengan bekerja dengan ikhlas dan menerima dengan senang hati. Proses nyetel jeroan juga menggambarkan karakter kerja keras karena berusaha untuk menjadi pribadi yang lebih baik.

\section{Nggawe Mondholan}

Proses nggawe mondholan yaitu membuat bagian atas yang biasa disebut payung lampu andong kereta kencana. Bentuk dari payung ini dapat berbentuk bulat, kerucut, prisma tergantung pada gaya lampu andong kereta kencana yang diingginkan. Keberadaan bagian atas atau payung pada lampu andong merupakan wujud dari doa pembuat dan pengguna lampu andong kereta kencana kepada Tuhan Yang Mahakuasa. Terkait dengan hal ini, Wakhid (wawancara tanggal 19 Maret 2018) menjelaskan seperti berikut ini.

Patri tapel jaran iku gambarno urip nang donyo iki sejatine ngusahak ke jogo keslametan urip e dewe lan urip e nang sak kitare awak e dewe nganggo coro ngerumat ciptaan ne Gusti Allah. Mondholan Iki ibarat gawe bentuk syukur lan pepiling marang Gusti sik ngayomi urip manungso.

Penyataan tersebut dapat dipahami bahwa patri tapal kuda atau sepatu kuda mengambarkan hidup di dunia itu harus berusaha menjaga keselamatan hidupnya sendiri dan orang lain untuk selalu ingat keberadaan dan ungkapan syukur kepada
Tuhan. Keberadaan payung pada lampu andong sekaligus mengingatkan pada pengrajin dan pengguna untuk selalu ingat kepada pelindung umat manusia, yaitu Tuhan.

Kandungan nilai karakter pada proses ini juga dipertegas dengan pernyataan Sukirman (wawancara pada tanggal 19 Maret 2018) bahwa ingat kepada Tuhan akan menuntun masyarakat Jawa pada falsafah memayu hayunning bawana, ambrasto dur hangkoro yang merupakan semboyan hidup masyarakat Jawa untuk selalu menegakkan kebajikan, kebenaran, dan keadilan di dunia. Maka manusia hidup harus selalu eling sangkan paraning dumadhi. Nilai karakter ini diartikan oleh Hariwijaya (2006:82) sebagai cita-cita membangun kesejahteraan masyarakat yang rahayu secara lahir dan rahayu secara batin.

Selain itu nilai spiritualitas yang terkandung di dalam konsep falsafah memayu hayuning bawana yakni mengajarkan kepada masyarakat untuk bersikap dan berperilaku dengan mengutamakan harmoni, keselarasan, keserasian dan keseimbangan. Termasuk menyelaraskan hubungan antara manusia dengan alam, manusia dengan manusia dan manusia dengan Tuhan dalam melaksanakan pekerjaan (Nugroho, 2019:354).

Pembuatan lampu andong yang masih mengedepankan tahapan-tahapan yang penuh makna dari sanalah pengrajin lampu andong kereta kencana mempunyai pandangan hidup yang bagus dan baik serta tidak pernah silau atas megahnya kehidupan. Dalam proses pengerjaanya, lampu andong kereta kencana juga mengajarkan nilai-nilai karakter kehidupan yang mengutamakan keselamatan, kebahagiaan batin, kesejahteraan lahir, serta menghilangkan sifat murka, serakah, tamak. Karakteristik pada proses pembuatan bagian payung 
pada lampu andong jelas sangat identik dengan nilai karakter religius. Dalam hal ini, Wakhid selaku pengrajin selalu memiliki prinsip kawula namung saderma, mobah mosik ndonyo kersaning hyang sukmo. Payung lampu ini ibarat manusia selalu berserah diri, lakukan sebisa mungkin, setelah itu serahkan kepada Tuhan (wawancara pada tanggal 17 Juni 2018).

Pada pembuatan mondholan atau payung lampu andong diibaratkan sebagai doa kepada Tuhan Yang Mahakuasa. Lampu yang menandakan bahwa semua kehidupan ini di serahkan oleh Yang Mahakuasa. Nilai karakter religius dalam proses ini seperti halnya nilai karakter yang dalam bahasaSutrisna Wibawa (2014) adalah sembah jiwa yang berarti mempersembahkan kehidupan kepada Tuhan. Cara yang dapat dilakukan dengan memelihara kehidupan rohani, waspada dalam perbuatan dan perkataan, selalu ingat akan hari akhir. Cara ini mendorong manusia untuk selalu berserah diri.

Bagian mondholan mengisyaratkan bahwa melakukan hal apapun masyarakat Jawa harus selalu mengutamakan keselamatan, dan bertujuan untuk mendapatkan kebahagiaan dan kesejahteraan. Dengan itu dapat menjadi motivasi atau semangat dalam menempuh karirnya. Menghindari sifat tamak dan serakah yang dapat merusak hubungan sosialnya dengan orang lain. Sifat serakah dan tamak sangat tidak cocok dengan masyarakat Jawa yang selalu menerima apa adanya dan hidup sederhana (Rizky, 2018:328-329).

Berdasarkan paparan proses pembuatan lampu andong dengan teknik patri tapal kuda dapat disimpulkan bahwa proses dan bentuknya memiliki kandungan nilai-nilai karakter yang selama ini dikenal dalam falsafah Jawa. Nilai-nilai ini dapat dijadikan pedoman hidup oleh pengrajin, penguna, bahkan masyarakat pada umumnya. Nilai-nilai karakter yang terkandung juga selaras dengan nilai-nilai karakter yang dicanangkan oleh Kemendiknas, sehingga dapat ditarik kesimpulan bahwa kandungan nilai-nilai karakter pada proses pembuatan lampu andong dapat diterapkann dalam kehidupan sehari hari dan teknik patri tapal kuda wajib dijaga kelestariannya.

Menurut pemaparan Widodo (wawancara pada tangggal 25 Juli 2018), yang merupakan juru kunci Kereta Kencana Keraton Ngayogyokarto menjelaskahn bahwa nilai-nilai karakter dalam proses pembuatan lampu andong sangat baik untuk dipahami dan diamalkan oleh generasi muda. Harapannya generasi muda bukan hanya menikmati hasil kerajinannya saja, tetapi juga memahami niali-nilai karakter falsafah Jawa yang terkandung dalam proses pembuatan. Tentunya cara ini perlu dilakukan untuk menjaga marwah orang Jawa yang njawani. Menggunakan istilah Muhammad Idrus (2012:122) bahwa perilaku manusia yang njawani adalah perilaku yang sesuai dengan nilai karakter yang terkandung dalam falsafah Jawa.

Untuk mewujudkan hal tersebut, masyarakat perlu memberdayakan potensi budaya, tardisi, kesenian, kerajinan yang ada. Potensi ini dapat diberdayakan melalui berbagai cara, salah satunya nilai-nilai karakter dalam proses teknik patri tapal kuda lampu andong. Nilai falsafah Jawa yang ada di dalamnya perlu direinterpretasi, direadaptasi, dan direkontekstualisasi untuk disumbangkan dalam rangka pembangunan karakter Bangsa. Nilai-nilai yang akan diinternalisasikan perlu dikomunikasikan dengan menggunakan bahasa yang tepat supaya mudah dipahami generasi selanjutnya (Saliman, 2019). Falsafah Jawa bukan hanya untuk orang Jawa. M. Syafii 
(2011:1) menegaskan bahwa filsafat Jawa pada dasarnya bersifat universal. Jadi filsafat Jawa yang memiliki nilai-nilai karakter bukan hanya diperuntukkan bagi masyarakat Jawa saja, tetapi juga bagi siapa pun yang ingin mempelajarinya.

\section{PENUTUP}

Ada banyak sekali nilai-nilai falsafah Jawa yang baik untuk dipahami dan diamalkan. Nilai-nilai tersebut dapat dijumpai pada pada kebudayaan maupun kesenian yang mencakup dari tradisi secara turuntemurun. Salah satu contohnya adalah kandungan nilai-nilai karakter falsafah Jawa dalam proses patri tapal kuda lampu andong di Kotagede Yogyakarta. Meskipun teknik ini bersifat tradisional, tetapi masih terjaga hingga kini dan masih digunakan oleh para pengrajin. Teknik pematrian menggunakan alat tapal kuda bukan bentuk ketertinggalan ataupun tidak paham teknik modern, melainkan patri tapal kuda adalah bentuk resistensi teknik patri kriya logam yang sudah mendarah-daging pada masyarakat Kotagede Yogyakarta.

Alasan kuat teknik tersebut masih digunakan karena kandungan nilai-nilai karakter falsafah Jawa yang tercermin pada dalam teknik patri tapal kuda lampu andong. Adapun nilai nilai karakter tersebut adalah (1) pada proses ngondel dan mengungsil terdapat falsafah aja adigang, adigung, adiguno yang memiliki kandungan karakter religius, toleransi dan peduli sosial; (2) pada proses ngharang baut patri terdapat falsafah urip iku urup, yang berarti sikap peduli sosial dan peduli lingkungan; (3) pada proses ngores rejoso terdapat falsafah alon-alon waton kelakon, yang bermaknakan tentang tanggung jawab; (4) pada proses nyetel jeroan terdapat falsafah nrimo ning pandum yang mengajarkan kejujuran dan kerja keras; dan (5) proses nggawe mon- dholan terdapat falsafah memayu hayuning bawana, ambrasta dur hangkara yang merupakan wujud manusia yang religius karena selalu bersyukur dan berserah diri kepada Tuhan YME.

\section{UCAPAN TERIMA KASIH}

Penulis menyampaikan ucapan terima kasih kepada ketua dewan redaksi Jurnal Pendidikan Karakter dengan dimuatnya hasil penelitian ini dalam Jurnal Pendidikan Karakter edisi sekarang ini. Selain itu, penulisjuga mengucapkan terima kasih atas bantuan dan kerja sama dari berbagai pihak mulai dari saat proses penelitian hingga terselesaikannya tulisan ini. Ucapan terima kasih terutama disampaikan kepada Bapak Sukirman, Bapak Wakhid, Bapak Slamet Riyanto, Bapak Bambang, dan Bapak Widodo yang telah bersedia memberikan informasi penelitian secara lengkap sehingga penelitian dapat terselesaikan.

\section{DAFTAR PUSTAKA}

Dewantara, K.H. (1997). Pemikiran, konsepsi, keteladanan, sikap merdeka I (Pendidikan). Yogyakarta: Majelis Luhur Persatuan Taman Siswa.

Hariwijaya. (2006). Falsafah hidup orang Jawa. Yogyakarta: Kanisius.

Idrus, M. (2012). Pendidikan karakter pada keluarga Jawa. Jurnal Pendidikan Karakter, 2(2), 118-130. DOI: https://doi.org/10.21831/jpk.v0i2.1297.

Jatirahayu, W. (2013). Kearifan lokal Jawa sebagai basis karakter kepemimpinan. Jurnal Diklus, 17(1), 264-280. Retrieved from: https://journal.uny.ac.id/index.php/jurnaldiklus/article /view/2895/2443.

Kemendiknas. (2010). Pengembangan pendidikan budaya dan karakter bangsa. Jakarta: Kementrian Pendidikan Nasional. 
Kurnia, R.D. (2017). 5 Filosofi hidup orang Jawa yang membuat mereka lebih bijaksana. Diunduh dari https://www.idntimes.com/life/inspiration/riza-diankurnia/ciri-khas-karakteristik-orangjawa-keluarga-jawa-yang-awet/full, pada 30 Oktober 2018.

Masrukhan, A. (2016). Pelaksanaan pendidikan karakter peduli sosial di SD Negeri Kotagede 5 Yogyakarta. BASIC EDUCATION, 5(29), 2.8122.820. Retrieved from: http://journal.student.uny.ac.id/ojs/index.php /pgsd/article/view/4855/4512.

Miles, M.B. \& Huberman, A.M. (1994). Qualitative data analysis: An expanded sourcebook. Oaks, London, Ney Delhi: Sage Publication.

Nugroho, S.S. (2019). Memayu hayuning bawana: Melacak spiritualitas transendensi hukum pengelolaan sumber daya alam berbasis kearifan masyarakat Jawa. Diunduh dari https:// publikasiilmiah.ums.ac.id/bitstream/handle/11617/ 9709/27.\%20Sigit\%20Sapto\%20Nugr oho $\% 20$ dan $\% 20$ Elviandri.pdf?sequen ce=1\&isAllowed=y, pada tanggal 19 Januari 2019.

Rizky, H. (2018). Menggali nilai filosofi budaya Jawa sebagai sumber karakter generasi milenial. Prosiding SNBK: Seminar Nasional Bimbingan dan Konseling, 2(1), 327-337. Retrieved from: http://prosiding.unipma.ac.id/index .php/SNBK/index.

Saliman. (2019). Membangun karakter bangsa melalui bahasa simbolik Jawa. Diunduh dari http://staff.uny.ac.id/sites/default/files/penelitian/Saliman, $\% 20 \mathrm{D}$ rs.\%20M.Pd./Pendidikan\%20karakte r\%20melalui\% 20bahasa\%20simbolik. pdf, pada tanggal 11 Januari 2019.
Sugiyono. (2013). Metode penelitian pendidikan:Pendekatan kuantitatif, kualitatif, dan RED. Bandung: Penerbit Alfabeta.

Sunaryo. H., dkk. (2000). Pengetahuan teknologi logam. Yogyakarta: Dinas Pendidikan Yogyakarta.

Suwardi. (2018). Bahan kuliah: Folklor Jawa. Diunduh dari http://staffnew.uny.ac.id/upload/131872518/pendidikan /materi+kuliah+folklor+jawa_0.pdf, pada tanggal 25 Juli 2018.

Syafii, M. (2011). Filosofi Jawa. Diunduh dari http://skp.unair.ac.id/repository/Guru-Indonesia/FilosofiJawa_MohammadSyafii_10832.pdf, tanggal 30 Oktober 2018.

Wibawa, S. (2014). Filsafat Jawa sumber pendidikan karakter. Diunduh dari https://daerah.sindonews.com/read/9001 82/22/ filsafat-jawa-sumber-pendidikan-karakter-1410342730, tanggal 23 Desember 2018.

Widodo, A., Akbar, S. \& Sujito. (2017). Analisis nilai-nilai falsafah Jawa dalam Buku Pitutur Luhur Budaya Jawa karya Gunawan Sumodiningrat sebagai sumber belajar pada pembelajaran IPS. Jurnal Penelitian dan Pendidikan IPS (JPPI), 11(2), 152-179. Retrieved from: http://ejournal.unikama.ac.id/index.php/JPPI/article/view/1887/1489.

Winarsih, I., Utomo, C.B., \& Ahmad, T.A. (2017). Peranan pembelajaran sejarah dalam penanaman nilai karakter religius dan nasionalisme di MAN Temanggung tahun ajaran 2016/2017. Indonesian Journal of History Education, 5(2), 22-29. Retrieved from: https://journal.unnes.ac.id/sju/inde x.php/ijhe/article/view/19920/9401 